\title{
God in America: Why Theology Is Not Simply the Concern of Philosophers
}

\author{
PAUL FROESE \\ CHRISTOPHER D. BADER
}

\begin{abstract}
As citizens of the most technologically advanced and economically developed country in the world, nearly all Americans stalwartly maintain their faith in God, much more so than residents of other postindustrial countries (Norris and Ingelhart 2004). But what is the content and meaning of this belief? Perhaps belief in God has become so pervasive in contemporary American culture that it reflects little about believers' deeper religious thoughts, identities, and actions. We find the opposite to be true. Outside the confines of seminaries, competing beliefs about who God is and what God wants have a clear and important connection to everyday religious life in the United States. Subtle distinctions in American images of God powerfully predict religious diversity as measured by belief in the truth of a single religious faith, religious devotion, and attitudes about the compatibility of secular and religious spheres. More specifically, we discern that American religious conservatism, in all its forms, can be aptly characterized by the belief that God is highly engaged in the world and particularly judgmental of human behavior.
\end{abstract}

The savage man has a savage God; the cruel man has a cruel God; the effeminate man has an effeminate God; while the good man lifts up holy hands to a God who rewards goodness.

The idea that one's God reflects something essential about oneself is a popular notion among religionists and nonreligionists alike. The Book of Genesis is clear on the matter: "And God said, Let us make man in our image after our likeness" (Genesis 1:26). Social scientists and psychologists tend to reverse this causal order and argue that individuals anthropomorphize the idea of the supernatural to reflect cultural values and desirable human traits (cf. Benson and Spilka 1973; Gorsuch and Smith 1983; Ladd, McIntosh, and Spilka 1998; Roberts 1989). Whether humans create their God or God creates humans, earthly images of God indicate how believers perceive the ultimate object of their religious devotion.

For this reason, differences of opinions about God matter deeply to believers and can inspire life changes, social movements, and societal conflicts. In fact, the history of religious conflict indicates that arguments over the character of God far outweigh arguments concerning God's existence. ${ }^{1}$ In other words, it is not usually the question of whether God exists that rouses religious passions but rather the question of who God is. While Americans generally report faith in God (nearly 96 percent of a national, random sample indicate some level of belief in the existence of $\operatorname{God}^{2}$ ), we find that when questioned about God's character an underlying diversity of opinion emerges. This article explores the substance of this variation and, more importantly, its effect on religious life in the United States.

Paul Froese is an Assistant Professor in the Sociology Department at Baylor University, One Bear Place \#97326, Waco, TX79798-7326.E-mail: Paul_Froese@baylor.edu.

Christopher D. Bader is an Assistant Professor in the Sociology Department at Baylor University.

Correspondence should be addressed to Paul Froese, Sociology Department, Baylor University, One Bear Place \#97326, Waco, TX 79798-7326; E-mail: Paul_Froese@baylor.edu. 
Green et al. (1996) and Woodberry and Smith (1998) aptly identify three distinct aspects of religiosity, which are complementary yet still independent of one another: (1) believing, (2) behaving, and (3) belonging. Of these three it appears that believing is often given less of a role in contemporary sociological literature and theorizing. Investigations into denominational differences and religious traditions as categorized by doctrinal history, organizational structure, or level of religious tension are common topics of research and emphasize the importance of social and group effects on individual religiosity (see Iannaccone 1994; Sherkat and Ellison 1999; Stark and Bainbridge 1985; Steensland et al. 2000).

Understanding patterns of religious activity is also a popular topic among social scientists who apply economic hypotheses and theories of normative constraint to explain variations in religious participation (see Akerlof 1997; Berheim 1995; Sen 1993). But religious belief tends to take a back seat in these projects and is usually assumed to be a latent outcome of social and normative constraints. This dearth of research into the content and substance of religious belief is unwarranted because at its most fundamental level religion is about belief. Without belief in the supernatural, religious membership and participation would be no different from any other social group commitment and would not merit special study. Therefore, we seek to begin a discussion about the content and importance of belief in God to complement and advance the numerous investigations of religious belonging and behavior.

Based on theoretical insights of past research and key debates within the philosophy of religion, we hypothesize that two aspects of God's character matter most to the attitudes and behaviors of believers. The first is the extent to which God interacts with the world; for some, God closely guides life on earth by pulling strings like an omnipotent puppeteer, while for others God's presence is not nearly so hands-on. A second important aspect is the extent to which God judges human behavior. For many Americans, God is angered by world affairs and takes sides in human disagreements, while other believers indicate that God mainly views us with love and compassion. Taken together, we argue that these aspects of God's character form the ontological basis of religious attitudes and behavior.

We use data from a national random sample of U.S. citizens, the Baylor Religion Survey (BRS), to examine how two key beliefs about God relate to the religious lives of Americans. We ultimately find that variation in conceptions of God powerfully predicts religious conservatism. First, images of God are significantly related to views of the Bible, the exclusivity of salvation, and judgments about the piety of others. Second, images of God predict levels of church attendance, frequency of religious experience, and one's desire to share one's faith with others. Finally, images of God are significantly correlated to attitudes about how closely secular and religious spheres should be connected. In all instances, Americans with more judgmental and engaged images of God indicate more religiously conservative beliefs, attitudes, and behaviors. For this reason, we conclude that images of God may be the unifying source from which religious conservatism and diversity can be better understood and provide some theoretical explanations of why.

\section{God and Religious Conservatism}

While debates concerning God have probably existed since the name of God was first uttered, arguments about the character of God took a decidedly modern turn during the Enlightenment. Indeed, God's place within the rapidly evolving philosophical, political, and scientific climate of the 17th century became a divisive issue among intellectuals and laid the basis for a new brand of theological diversity. Intellectual scholar Matthew Stewart (2006:17) argues that "contemporary debates concerning the separation of church and state, the clash of civilizations, and the theory of natural selection, to name just a few examples, are all continuations of the discussion that began in November 1676." Stewart is referring to a meeting between the eminent philosophers Baruch Spinoza and Gottfried Leibniz. While Leibniz and Spinoza both agreed that God existed, they disagreed about God's form and function. Famously, Spinoza posited a God who was 
indistinguishable from the laws of nature-in effect, a God who was compatible and yielding to a modern scientific worldview ${ }^{3}$ (Spinoza 1955). Leibniz was offended by "Spinoza's God" and advocated a more biblical conception of God-one who thinks, feels, judges, and exists independently of the laws of nature (Leibniz 1961).

The Spinoza-Leibniz debate represents the very essence of an ongoing tension between everevolving scientific and philosophical worldviews and the idea of a fixed and everlasting God. This is not to say that the idea of God is incompatible with modernity. Rather, certain forms of religious belief clash with emergent scientific knowledge, ever expanding moral codes, and modern political creeds while other forms of religious belief do not. What distinguishes religious opposition to modernity from religious compatibility is a topic of much discussion.

The popular media and many in the social science community use the phrase "religious conservative" to describe a certain type of religious individual who is more traditional in his or her beliefs and behavior. ${ }^{4}$ But what is the essence of being a religious conservative? Often, religious conservatism is measured by levels of church attendance, views concerning the literalness of the Bible, denominational type, religious identity labels such as "born again," and attitudes about moral strictness. We posit that all of these indicators of religious conservatism are related to and reflect underlying theological differences concerning God's relationship to the world. At its heart, religious conservatism, in all its forms, is really about beliefs concerning the authority and disposition of God.

Spinoza's God represents an attempt to integrate the idea of God with a scientific ordering of the universe; he did this by describing a God who is simply a part of the natural order (Spinoza 1955). Leibniz worried that subsuming God within the natural world would lead to the profane denial of God's ultimate autonomy and authority (Leibniz 1961). As Georg Simmel ([1909]1997:53) notes, "[a] deity that is subsumed into a unity with the whole of existence cannot possibly possess any power, because there would be no separate object to which He could apply such power." Without autonomy, Leibniz feared that the idea of God would be rendered essentially meaningless and those who believed in such a God would abandon their religious piety, involvement, and devotion.

Leibniz's concern may be well founded because the autonomy of God seems central to how individuals understand their natural and social worlds and, in turn, how they will react to them. A highly autonomous God intercedes in earthly affairs with inexplicable acts of divine intervention and guidance. Armed with this conception of God, individuals are more likely to attribute worldly events, like tsunamis, economic downturns, or even finding a good parking space, to God's will. Consequently, we expect that these individuals will be more diligent in their religious involvement, firm in their religious commitments, and more prone to ignore distinctions between religious and secular spheres of inquiry. In contrast, a less autonomous or engaged God will not upset the natural processes of biology, ecology, or the daily workings of the social world. We expect that individuals who believe in a less autonomous or less engaged God will tend to be less committed to traditional religious attitudes and strictures and feel that their religious beliefs are completely compatible with the natural sciences and secular politics.

But intimately related to the idea of God's involvement in the world is God's disposition. Is an involved God all-forgiving and nonjudgmental? Or does God monitor the world with a wrathful eye, condemning behavior that does not fit within strict commandments? For those who believe in an autonomous and engaged God, God may manifest himself in the world in different ways. Within the Hebrew Scriptures, God is depicted at times as extremely wrathful and punishing while, at other times, boundlessly merciful and loving. The extent to which Christians concentrate on the God who "standeth to judge the peoples" (Amos 3:13) or the God who shows "mercy unto thousands" (Exodus 20:6) is important to how they think God will interact with the world. ${ }^{5}$ Andrew Greeley $(1988,1989,1991,1993,1995)$ has investigated the correlation between the extent to which one views God as a motherly and loving figure and one's political and social views. Interestingly, he finds strong positive relationships between more compassionate images 
of God and more compassionate opinions about others. Greeley's work indicates that we must pay attention to God's perceived disposition in order to understand the impact of religious belief on the individual.

The Spinoza-Leibniz debate about the nature of God cuts to the heart of what distinguishes religious conservatives from religious liberals. In the United States, where belief in God is relatively uncontested, ${ }^{6}$ we expect that differences of opinion concerning God's engagement with the world and God's judgment of the world will best predict variation in the multiple measures used to indicate religious conservatism. Our analyses test this claim.

\section{Measuring God}

The data used in this study are from the first (2005) wave of the Baylor Religion Survey (BRS). The Baylor Religion Survey was designed using the General Social Survey as a model. On a biannual basis the GSS provides a snapshot of American attitudes and beliefs on a variety of different topics through a combination of fixed content and rotating topic modules. Other than occasional modules devoted to religion, such as in 1991 and 1998, the GSS has relatively little space to devote to the topic. Although it contains questions on a variety of areas ranging from civic engagement to political tolerance, the majority of the fixed content of the Baylor Religion Survey is devoted to religion items. In the future rotating content modules will allow examinations of the relationship between religiosity and a variety of different behaviors and attitudes. Consisting of a random, national sample of 1,721 U.S. citizens, the Baylor Religion Survey was administered and collected by the Gallup Organization. For further detail about the methodology behind the survey and how it compares to other national surveys, see Bader, Mencken, and Froese (2007), located in the issue.

The BRS includes numerous questions about God. In addition to whether they believe in God, respondents are asked to indicate how well a variety of adjectives describe God, and to indicate their level of agreement or disagreement with a variety of statements about God's involvement in the world and general disposition. Using these items we created two distinct measures of God's form and function-God's level of engagement in the world and God's level of judgment.

God's level of engagement is a simple additive scale of eight items tapping the respondent's belief about God's interest and involvement in the world. Six of those items ask respondents their level of agreement (on a five-point Likert scale) with the following descriptions of God: "removed from worldly affairs," "removed from my personal affairs," "concerned with the wellbeing of the world," "concerned with my personal well-being," "directly involved in worldly affairs," and "directly involved in my affairs." Two additional items ask respondents how well the adjectives "Distant," and "Ever-present" describe God: "not at all," "not very well," "undecided," "somewhat well," or "very well." Items were flipped as necessary such that higher scores equal higher levels of perceived engagement. The resulting index, hereafter referred to as God's Level of Engagement, ranged from 8 to 40 with a mean of 30.64 (alpha $=0.91$ ).

We measured God's perceived level of judgment by summing six items. Respondents are asked if they agree that God is "angered by human sins," and "angered by my sins." They are also asked how well the adjectives "critical," "punishing," "severe," and "wrathful" describe God. As with the items regarding God's engagement, all are on five-point Likert-type scales. The final index has an alpha of 0.85 . Scores range from 6 to 30 with a mean of 17.04.

\section{Religious Conservatism Measures}

We wish to test whether views of God as judgmental and very engaged will be positively related to religious conservatism. In service to this goal, we use multiple measures of religious conservatism, subcategorized into: (1) indicators of conservative religious beliefs; (2) levels of religious participation and involvement; and (3) attitudes concerning the role of religion in government. 
Belief measures include indicators of biblical literalism and beliefs about the exclusivity of salvation. We measure exclusivity using a general item about ecumenicalism and three items related to admittance into heaven. Respondents were asked to choose which one statement comes closest to their view of religious salvation. The statements included "I do not believe in religious salvation," "Many religions lead to salvation," "My religion is the one, true faith that leads to salvation," and "I don't know." We contrasted those who believe their religion to be the one, true faith with all others in a logistic regression.

Another series of items asks respondents to estimate how many people in certain groups will get into heaven - all, most, about half, a few, none, or "no opinion." Respondents are asked about average Americans, personal friends, neighbors, family members, Christians, and non-Christians. People are likely to know the faith of their friends, neighbors, and family members. For space reasons, we focus on those outside the respondent's inner circle-average Americans, Christians, and non-Christians. We created three dummy variables. We contrast those who believe that all or most average Americans and all or most Christians will go to heaven with all others. For the non-Christians item, we contrast those who answer "none" (i.e., no non-Christians will get into heaven) with all other respondents.

Our religious involvement indicators include frequency of church attendance, number of religious experiences, and the frequency of talking about religion with friends and strangers. The religious experiences indicator is a simple count of nine different experiences. ${ }^{7}$ The summed index ranges from 0 to 9 with an alpha of $0.78 .{ }^{8}$ Respondents were also asked how often in the past month they had spoken to two different groups about religion, friends and strangers. Possible responses included not at all, 1-2 times, 3-4 times, or 5 or more times. We summed these items to create a measure of "faith sharing." The final index had an alpha of 0.85 .

Our measures of attitudes concerning the relationship between the secular and the religion include indicators of views on the relationship between church and state, and beliefs about God's position on political issues. A series of items on the Baylor Religion Survey ask respondents if the federal government should be involved in activities ranging from spending more on the military to doing more to protect the environment. Responses were on a five-point Likert scale. Four of these items are about government involvement in religious affairs: "advocate Christian values," "defend Christian values," "fund faith-based organizations," and "allow the display of religious symbols in public places." We summed these items to create an overall measure of the respondent's "sacralization ideology" (alpha = 0.86). We use the term "sacralization," which means that "there is little differentiation between religious and secular institutions and that the primary aspects of life, from family to politics, are suffused with religious symbols, rhetoric, and ritual" (Stark and Finke 2000:284). Our sacralization ideology index measures the extent to which respondents believe that the strict division between governmental and religious institutions should be flexible and permeable. Higher scores indicate that the respondent desires less separation between church and state.

We measure the respondent's beliefs about God and politics using two Likert-based items. The first asks respondents their level of agreement with the statement "God favors one political party in the United States." The second asks the respondent if "God favors the United States in worldly affairs."

\section{Control Variables}

Several demographic controls are used in our analyses. OLS and logistic regression models included the following controls. Race $(1=$ white $)$, gender $(1=$ female $)$, education $(1=$ at least some college), and region $(1=$ South $)$ are included as dichotomous variables. We entered income as two dichotomous variables. The U.S. Census Bureau reports the 2005 median U.S. household income to be $\$ 46,326$. This median income is contained within the response category $\$ 35,000$ $\$ 50,000$. We created a "low-income" variable for those making less than $\$ 35,000$ a year and a 
"high-income" variable for those making more than $\$ 50,000$ a year. Age is entered as a numeric scale ranging from 18 to 93 . In order to determine if there might be cohort effects on our outcome measures we also ran our models with a series of dummies for age (18-30, 31-40, 41-50, 51-60, $61-70,71$ and over). ${ }^{9}$ Since the effects of these dummy variables were limited, we elected to use a more concise presentation. Any significant effects for age cohorts are footnoted under their respective tables.

In our final model that examines the connection between religion and politics, we control for political party identity, using a variable in which respondents place themselves on a sevenpoint scale ranging from strong Democrat to strong Republican; higher scores represent leanings toward the Democratic Party. For more detail about the demographic breakdown of the sample, see Bader, Mencken, and Froese (2007) in this issue.

We control for a variety of religion measures in our analyses. To ensure that images of God are not simple proxy measures for biblical literalism or church attendance we include both items as controls (when not a dependent variable). Church attendance ranges from 1 (never) to 9 (several times a week). When used as an independent variable we contrast frequent attenders (those who attend once a week or more) with all others. As a measure of literalism, we use an item that asks respondents about their view of the Bible by selecting from the categories "The Bible is an ancient book of history and legends," "The Bible contains some human error," "The Bible is perfectly true, but it should not be taken literally, word-for-word. We must interpret its meaning," and "The Bible means exactly what it says. It should be taken literally, word-for-word, on all subjects." We treated this item as a continuous measure of literalism, since higher scores indicate increasingly literal views of the Bible. To control for denomination, we include a modified version of the RELTRAD typology developed by Steensland et al. (2000), using those with no religion as a comparison group. As do Steensland et al. (2000) we place individuals into the categories Black Protestant, Evangelical Protestant, Mainline Protestant, Catholic, Jewish, Other Religion, and None based upon their stated denomination. In all of our models we used Evangelical Protestant as our contrast category. However, we also consider an additional item that asks respondents to provide the name and location of their church. See Dougherty, Johnson, and Polson (2007) for a detailed description of this modified RELTRAD typology. ${ }^{10}$

\section{Analytic Strategy}

There are two basic steps in our analysis. First, we seek to understand whether Americans are generally more attracted to the impersonal essence of God posited by Spinoza, or the omnipotent creator of Leibniz. As citizens of the most technological advanced and economically developed country in the world, we expect that Americans will probably hold images of God that are more compatible with modernity; in other words, Americans should tend to view God in ways similar to Spinoza. Second, we test whether certain images of God have a negative affect on religious devotion as Leibniz predicted. To do this, we analyze whether belief in Spinoza's God reduces levels of religious conservatism.

\section{God ANd the People}

Figure 1 provides a histogram of God's perceived engagement in the world. It is immediately evident that relatively few Americans view God as completely removed from the world. In fact, approximately 15.6 percent of the sample scored the highest possible score on God's engagement, compared to the less than 1 percent ( 0.8 percent) who view God in the most distant terms. Surprisingly, given the level of modernization in the United States, few Americans indicate that they believe in a God similar to that of Spinoza's God of Nature.

God's engagement and God's judgment are significantly correlated $\left(0.378^{* *}\right)$, so those who view God as more engaged in the world also have a tendency to believe that God is more critical of it. While Americans clearly view God as engaged, opinions about God's level of judgment more 


\section{FIGURE 1 \\ DISTRIBUTION OF BELIEFS ABOUT GOD'S LEVEL OF ENGAGEMENT}

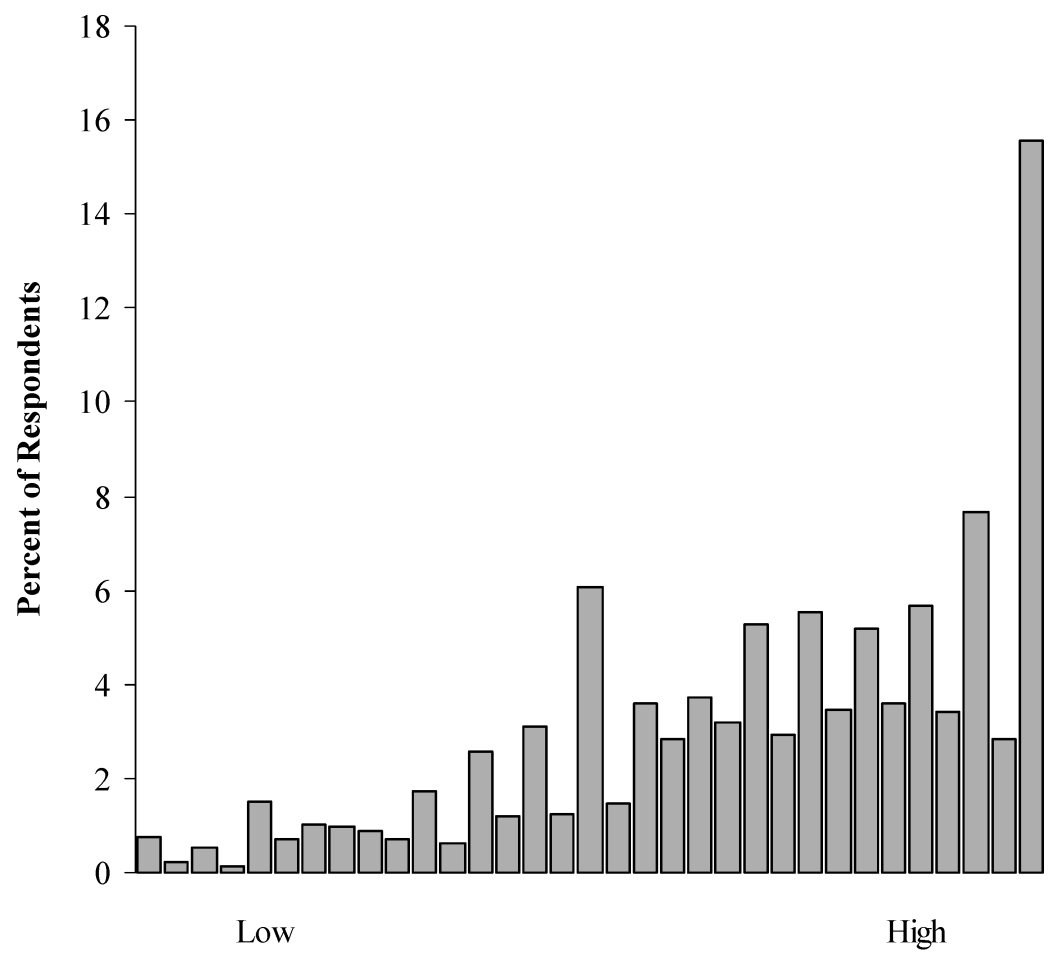

Level of God's Engagement

Note: Mean $=30.64 ;$ Standard Deviation $=7.94$.

closely approximate a normal curve (see Figure 2). Most respondents fall somewhere between viewing God as an entirely benevolent figure or as an angry judge. These findings indicate that while most Americans agree that God is engaged in the world, they believe that God's engagement may come in very different forms, ranging from punitive acts of divine justice to loving acts of divine grace.

How these images of God relate to various demographic characteristics reveal some clear patterns of how images of God differ within the American public. Table 1 presents OLS regressions for each of our God measures on various demographics. Women tend to view God in more engaged but also less judgmental terms. Indeed, gender has the strongest effect of the demographics on views of God's engagement. Region was also significantly related to images of God, with southerners believing in a more active and judgmental God. Nonwhites also tend to view God in more judgmental terms. The strongest nonreligious predictor of God's judgment is education. Those with at least some college tend to view God both as less judgmental and less involved in the world.

These findings indicate that images of God are closely connected to social economic status. Individuals lacking the opportunities opened by a college education tend to view God as very active in their worlds. This may appear somewhat ironic, as God does not appear to be blessing the disadvantaged. However, the God of the disadvantaged also appears very judgmental. The object of this judgment is unknown but we hypothesize that those "without" may feel that God is not pleased with the current social order. In contrast, individuals with more education are much less likely to view God as judgmental, perhaps because the social order also appears quite forgiving.

The strong education effect may also provide some insights into the process of secularization. We hypothesize that education may lead individuals to hold more "Spinoza-like" images of God, 
FIGURE 2

DISTRIBUTION OF BELIEFS ABOUT GOD'S LEVEL OF JUDGMENT/ANGER

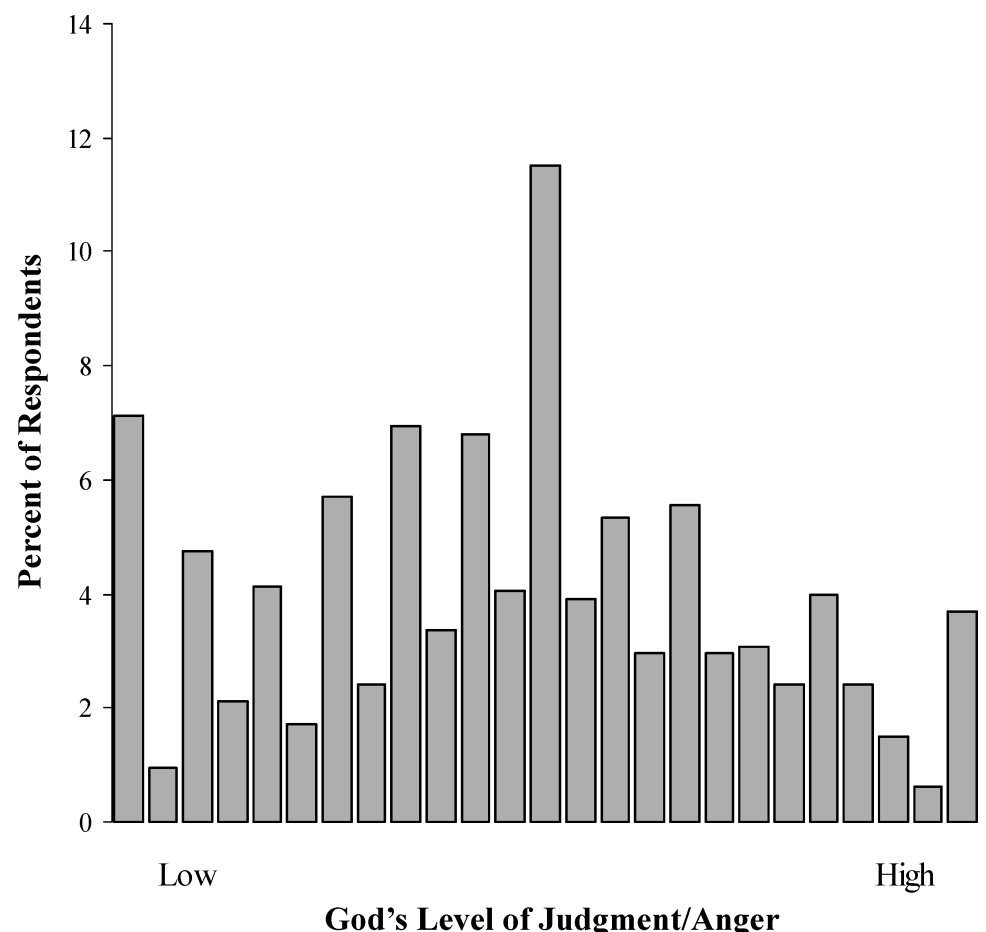

Note $:$ Mean $=17.04 ;$ Standard Deviation $=6.43$.

making them more likely to view God as a part of the natural order of things. Whether this is a function of a greater acceptance of current scientific knowledge or a product of satisfaction with the comforts of the modern world is unknown. Perhaps education leads one to dismiss the idea that God continually intervenes in the world or perhaps material riches lead one to dispel the idea that God's intervention is a necessary component to success.

Gender and education remain significant predictors of both measures of God when controlling for religious tradition RELTRAD (see Model 2 for each variable). Also we find that Evangelical Protestants hold more judgmental and engaged images of God than any other religious group in the United States with the exception of Black Protestants.

\section{God ANd Hellfire}

Table 2 provides the results of five logistic regression models for biblical literalism, and opinions about the exclusivity of salvation. The models include our demographic controls, the RELTRAD typology, church attendance, and our engaged and judgmental God measures. For Model 1, we dichotomized biblical literalism, such that we contrast people who believe the Bible is to be taken literally and is without error to all others. Biblical literalism is included as an independent variable, in its original form, in the final four regressions. The association of images of God with these outcome measures demonstrates the complexity of defining religious conservatism.

The meaning of biblical literalism is not completely clear. The Bible contains a wealth of descriptions about God, the social world, and the moral order. Consequently, when an individual claims to read the Bible literally, it remains unknown how he or she will reconcile and integrate 
TABLE 1

OLS REGRESSIONS OF GOD'S LEVEL OF JUDGMENT AND GOD'S LEVEL OF ENGAGEMENT ON SELECT DEMOGRAPHICS (STANDARDIZED COEFFICIENTS)

\begin{tabular}{lccccc}
\hline & \multicolumn{2}{c}{ God's Level of Judgment } & & \multicolumn{2}{c}{ God's Level of Engagement } \\
\cline { 2 - 3 } & Model 1 & Model 2 & & Model 1 & Model 2 \\
\hline Female & $-0.063^{*}$ & $-0.075^{* *}$ & & $0.191^{* *}$ & $0.168^{* *}$ \\
White & $-0.093^{* *}$ & $-0.087^{* *}$ & & -0.041 & -0.026 \\
College education & $-0.146^{* *}$ & $-0.089^{* *}$ & & $-0.139^{* *}$ & $-0.063^{*}$ \\
Income $<$ \$35k & 0.067 & $0.074^{*}$ & & 0.038 & 0.048 \\
Income $>$ \$50k & -0.056 & -0.062 & & 0.015 & -0.009 \\
Age & -0.033 & -0.034 & & 0.004 & -0.023 \\
Region (1 = South) & $0.148^{* *}$ & $0.062^{*}$ & & $0.094^{* *}$ & -0.011 \\
Religious Identity & & & & \\
Black Protestant & - & -0.034 & & - & -0.020 \\
Mainline Protestant & - & $-0.183^{* *}$ & & - & $-0.185^{* *}$ \\
Roman Catholic & - & $-0.233^{* *}$ & & - & $-0.166^{* *}$ \\
Jewish & - & $-0.133^{* *}$ & & - & $-0.133^{* *}$ \\
Other religion & - & $-0.191^{* *}$ & & - & $-0.107^{* *}$ \\
No religion & - & $-0.310^{* *}$ & & - & $-0.545^{* *}$ \\
$R^{2}$ & 0.073 & 0.180 & & 0.075 & 0.315 \\
$N$ & 1,293 & 1,263 & 1,286 & 1,251 \\
\hline
\end{tabular}

${ }^{*} p<0.05 ;{ }^{* *} p<0.01$.

a In additional models, we entered age as a series of dummy variables (18-30, 31-40, 41-50, 51-60, $61-70,71$ and over) with $41-50$ as the contrast category. Age group 51-60 views God as significantly less judgmental. Age groups 31-40, 51-60, and 71+ view God in less active terms.

${ }^{\mathrm{b}}$ Contrast category $=$ Evangelical Protestant.

the tremendous complexity of the multiple books and messages contained within. In theory, individuals who interpret the Bible literally can espouse radically differing theological, moral, and political worldviews depending on which aspects of the Bible they deem more salient or relevant than others. With regard to images God, we expect that individuals who interpret the Bible literally are most likely to understand God as very active in the world and willing to express judgment; both of these images of God are abundantly illustrated throughout the Bible. As expected, there are significant and positive relationships between God's level of judgment and God's level of engagement and biblical literalism. Namely, people with conceptions of the supernatural as extremely autonomous, active, and retributive tend toward literal interpretations of the Bible.

The exclusivity of salvation is also strongly related to certain images of God. Individuals who view God as more engaged and judgmental tend to believe that their religious faith is the only path to salvation. Believing that one has the "correct" faith does not necessarily mean that the less enlightened will suffer for their error. One might believe in a God that will forgive those who make the "wrong" choice. However, it does not appear that Americans make this distinction. Even when controlling for biblical literalism, those with judgmental and engaged views of God are more condemning of non-Christians.

Indeed, the models predicting opinions regarding heaven reveal key differences between engaged and judgmental God measures and biblical literalism. Those who attend church more often and those who see God as judgmental are less likely to believe that most Americans will make 


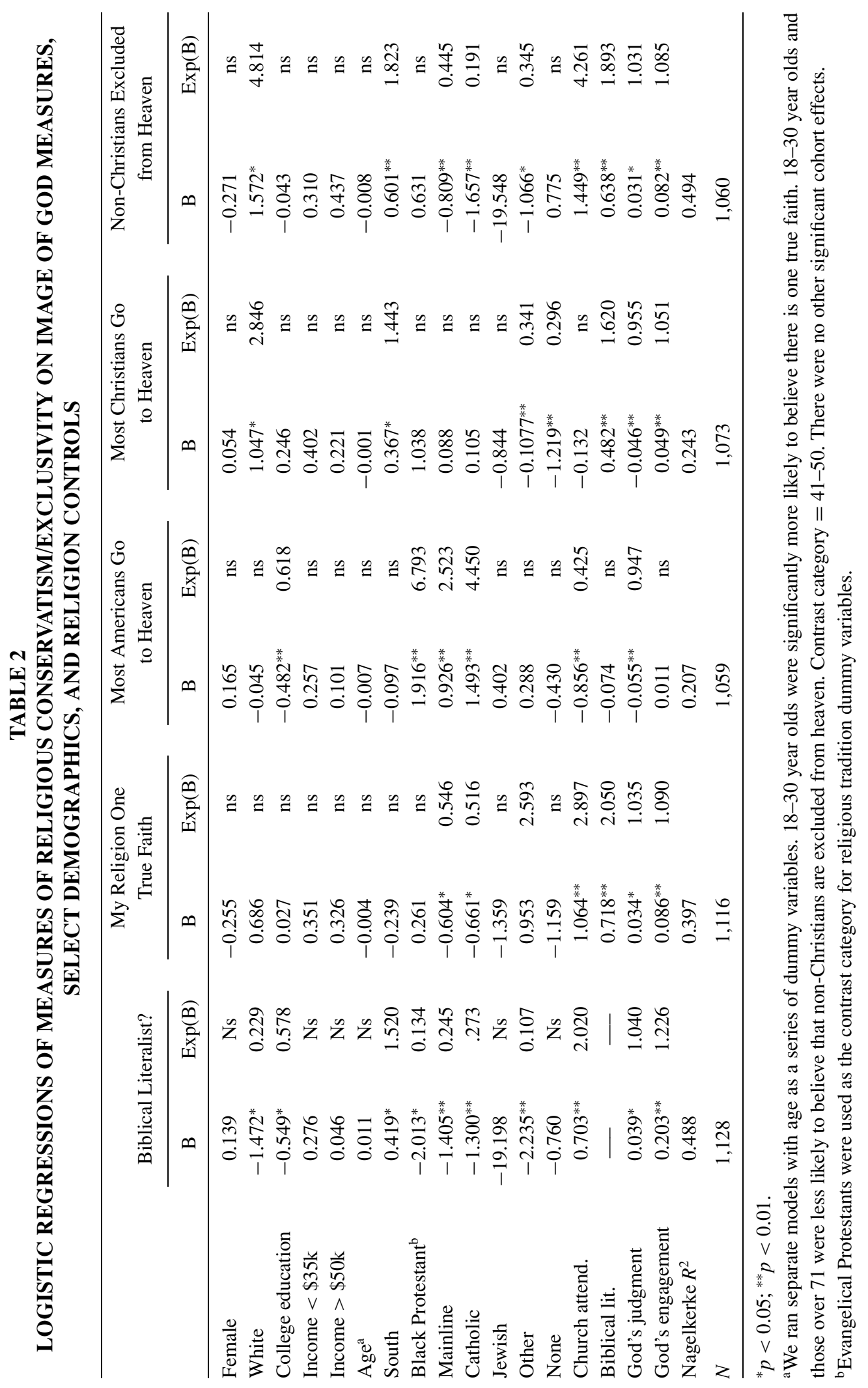


it to heaven but neither God's engagement nor biblical literalism predicts the average American's fate in the afterlife. Church attendance and all three religious belief measures predict the exclusion of non-Christians from heaven. Those who attend with greater frequency and view the Bible in more literal terms see God as engaged in the world and view God as judgmental are less likely to grant non-Christians access to heaven.

The model predicting whether the respondent believes most Christians will go to heaven is telling. Beliefs about God's engagement and biblical literalism are both significantly related to the belief that most Christians will go to heaven. Notably, those with judgmental God images are less likely to grant most Christians access to heaven. This reveals an important distinction between a judgmental image of God and other measures of religious conservatism. While those with higher conservatism scores on biblical literalism and church attendance tend to feel that being Christian is sufficient for entry into heaven, those who believe in an judgmental God are more restrictive. In other words, those who believe in a judgmental God are the most conservative of religious conservatives. Only very special Christians will avoid hellfire, in their view.

These findings fit with a growing body of literature that investigates the specific issue of how images of God relate to attitudes concerning punitive justice in this life. Compatible with our findings, Unnever, Cullen, and Applegate (2005) use 1998 GSS data to show that God's level of graciousness is negatively related to advocacy of capital punishment (see also Unnever, Cullen, and Bartkowski 2006). Ellison (1991) also finds that, for southerners, hierarchical images of God are related to strong support for retaliatory violence. Finally, Froese, Bader, and Smith (forthcoming) demonstrate with GSS data that wrathful images of God predict higher levels of political intolerance. All of these studies indicate that more judgmental and authoritarian images of God are closely allied to the attitude that violators of social or religious norms deserve to face harsh punitive measures.

In sum, across all of the models we find belief in a judgmental God to be the most consistent of the belief measures in predicting religious conservatism and exclusivity. Belief in a judgmental God appears to provide the clearest measure of whether one is willing to condemn others for perceived improprieties and view them as damned to hell.

\section{God ANd the Pews}

Table 3 examines how engaged and judgmental images of God relate to religious behaviors such as church attendance, religious experiences, and proselytizing. We might predict that belief in a judgmental God will have a powerful effect on religious behaviors. After all, if God is judgmental and critical of humans, we might expect increased efforts to please him. Surprisingly, we find that this is not the case.

Only two religion variables are consistent predictors across the models_-biblical literalism and God's level of engagement. Biblical literalism significantly increases the frequency of church attendance the number of religious experiences reported, and one's frequency of proselytization in the past month.

God's level of engagement was the strongest predictor of church attendance. We would expect that people who believe that God is ever-present and engaged in worldly affairs would be more likely to claim religious experiences. A distant God is unlikely to empower individuals to speak in tongues unknown to the speaker, or engage in miraculous healings. Indeed, belief in an engaged God is also the strongest predictor of reported religious experiences. Belief in a present God also leads to a desire to share that belief, as an engaged God significantly increases the willingness of individuals to talk about religion to others.

Belief in a judgmental God was not significantly related to any of the religious behaviors even when we remove the measure of biblical literalism from the models. This reveals an important distinction between our two God measures. God's judgment is clearly unrelated to religious 
TABLE 3

OLS REGRESSIONS OF RELIGIOUS BEHAVIORS ON IMAGE OF GOD MEASURES, SELECT DEMOGRAPHICS, AND RELIGION CONTROLS (STANDARDIZED BETAS REPORTED)

\begin{tabular}{lccc}
\hline & Church Attendance & Religious Experiences & Sharing Faith with Others \\
\hline Controls & & & \\
Female & -0.004 & 0.006 & 0.018 \\
White & -0.045 & -0.047 & $-0.091^{* *}$ \\
College education & 0.048 & 0.032 & -0.039 \\
Income $<\$ 35 \mathrm{k}$ & -0.003 & 0.054 & 0.045 \\
Income $>$ \$50k & $0.090^{* *}$ & $-0.064^{*}$ & -0.063 \\
Age & $0.087^{* *}$ & $-0.052^{*}$ & -0.019 \\
Region (1=South) & $0.061^{*}$ & 0.031 & 0.006 \\
Religious Identity & & & \\
Black Protestant & -0.016 & -0.012 & -0.018 \\
Mainline Prot. & 0.005 & $-0.072^{*}$ & -0.042 \\
Catholic & 0.023 & $-0.140^{* *}$ & $-0.086^{* *}$ \\
Jewish & 0.018 & -0.043 & -0.012 \\
Other religion & 0.027 & 0.023 & 0.013 \\
None & $-0.114^{* *}$ & -0.010 & -0.016 \\
Church attendance & - & $0.181^{* *}$ & $0.223^{* *}$ \\
Religious Beliefs & & & \\
Biblical literalism & $0.278^{* *}$ & $0.181^{* *}$ & $0.107^{* *}$ \\
God's judgment & -0.019 & 0.012 & 0.032 \\
God's engagement & $0.371^{* *}$ & $0.271^{* *}$ & $0.192^{* *}$ \\
$R^{2}$ & 0.431 & 0.363 & 0.254 \\
$N$ & 1,128 & 1,128 & 1,113 \\
\hline
\end{tabular}

$* p<0.05 ; * * p<0.01$.

${ }^{a}$ We ran separate models with age as a series of dummy variables. Those over 60 showed higher levels of church attendance. Those over 60 also had significantly fewer religious experiences. Those between the ages of 31-40 and 61-70 shared their faith less often. Contrast category $=41-50$.

${ }^{b}$ Evangelical Protestants were used as the contrast category for religious tradition dummy variables.

behaviors. We conclude that people are probably not scared into the pews. Instead, individuals who are religiously active tend to believe in a God who is engaged in the world and their lives. These individuals express close relationships with a God who is not necessarily judgmental or condemning. Based on these findings, we can theorize that religious participation tends to be about forming a close attachment with the supernatural. And we hypothesize that additional fire and brimstone sermons will not have their intended outcome of inspiring more devout behavior.

\section{GOD AND THE WORLD}

Our final analyses examine attitudes about the connection between religious and secular spheres. We regress sacralization ideology, God's perceived favoritism toward a particular political party, and God's perceived favoritism toward the United States on our control variables, religious identity measures and religious beliefs (see Table 4). Given the political nature of these final analyses, we included a control for political party identity. Higher values on the political identity variable equate to Democrat leanings. 
TABLE 4

OLS REGRESSIONS OF ATTITUDES REGARDING THE ROLE OF RELIGION IN GOVERNMENT ON IMAGE OF GOD MEASURES, SELECT DEMOGRAPHICS, AND RELIGION CONTROLS

\begin{tabular}{lccc}
\hline & Sacralization & Does God & Does God \\
& Ideology & $\begin{array}{c}\text { Favor a } \\
\text { Political Party? }\end{array}$ & $\begin{array}{c}\text { Favor the } \\
\text { United States? }\end{array}$ \\
\hline Controls & & & \\
Female & 0.031 & 0.015 & -0.028 \\
White & -0.018 & 0.019 & -0.050 \\
College education & $-0.051^{*}$ & -0.008 & -0.050 \\
Income < \$35k & 0.023 & $0.101^{* *}$ & 0.038 \\
Income > \$50k & -0.012 & 0.017 & -0.029 \\
Age & $0.047^{*}$ & -0.056 & 0.012 \\
Region (1=South) & -0.013 & 0.034 & 0.010 \\
Leans Democrat & $-0.232^{* *}$ & $-0.208^{* *}$ & $-0.253^{* *}$ \\
Religious Identity: & & & -0.043 \\
Black Protestant & & -0.035 & 0.005 \\
Mainline Prot. & 0.005 & 0.003 & -0.009 \\
Catholic & $-0.078^{* *}$ & 0.029 & -0.022 \\
Jewish & -0.045 & 0.007 & 0.014 \\
Other religion & $-0.094^{* *}$ & -0.029 & $-0.069^{*}$ \\
None & $-0.091^{* *}$ & -0.032 & -0.049 \\
Church attendance & $-0.097^{* *}$ & $-0.073^{*}$ & \\
Religious Beliefs & -0.002 & & $0.150^{* *}$ \\
Biblical literalism & & $0.197^{* *}$ & $0.094^{* *}$ \\
God's judgment & $0.267^{* *}$ & $0.098^{* *}$ & $0.152^{* *}$ \\
God's engagement & $0.163^{* *}$ & 0.044 & 0.273 \\
$R^{2}$ & $0.224^{* *}$ & 0.196 & 1,049 \\
$N$ (1, & 0.584 & 1,048 &
\end{tabular}

${ }^{*} p<0.05 ;{ }^{* *} p<0.01$.

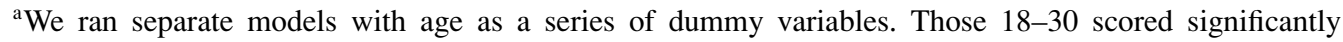
lower on the sacralization ideology scale. 18-30 years olds were also more likely to think God favors a political party. Finally, 31-40 year olds were more likely to believe God favors the United States. Contrast category $=41-50$.

${ }^{b}$ Evangelical Protestants were used as the contrast category for religious tradition dummy variables.

Other than political party identity, the demographic controls have limited effect on our three outcome measures. Controlling for other factors, a college education decreases the desire for church/state integration. Older people desire tighter church/state integration but are less likely to believe that God favors the United States in world affairs or a certain political party. Those with incomes under $\$ 35 \mathrm{~K}$ are more likely to believe that God favors a political party. The religious tradition variables also have mixed effects. For example, religious tradition has no effect on God's favoritism for a political party. But Mainline Protestants, Jews, those of other religions, and those with no religion desire less church-state integration than Evangelicals.

As would be expected, political party identity is significantly related to all three outcome measures. Those who identify with Democrats desire greater separation between the church and 
the state. They are also less likely to believe that God favors their political party or the United States in world politics.

However, even when controlling for political party identity, images of God still have a powerful effect upon attitudes about the role of religion in government. God's engagement is a significant predictor of sacralization ideology and the opinion that God favors the United States in world affairs. However, it does not predict opinions about God's favor toward a political party. The two most consistent predictors were biblical literalism and God's judgment. Those who have a literal interpretation of the Bible want stronger church/state ties, and believe that God favors a political party and the United States. While an image of God as judgmental does not affect specifically religious behaviors, it has a powerful impact on beliefs about the role of religion in the world. To the extent that a person views God as judgmental he or she will desire a tighter integration between the church and the state. Those who see God as judgmental also believe that "He" takes sides in world affairs by favoring certain political parties and granting special favor to the United States.

Williams (1999:10) notes that early American advocacy for the collaboration between religious and social institutions was predicated on a belief in "the total otherness of a transcendent God and the attendant belief that all human institutions were tainted with sin and therefore mutable." (Also see Wuthnow 1988.) Interestingly, Puritans with this perception of God believed that "the Church was not required to save souls, that was the sole province of an awesome Creator and Judge, but to gather the elect and shepherd the Community toward the creation of the New Jerusalem" (Williams 1999:10). In contemporary America, we similarly find that it is believers with judgmental images of God who not only feel that most Americans are condemned to hell but also see the need to bring religion into American public life. And these two attitudes are conjoined in the idea that a judgmental God wants believers to build a devout community around social institutions that put sinners in their rightful place but does not necessarily save them.

\section{Conclusion}

Using detailed questions from the Baylor Religion Survey (BRS) and armed with two indicators of God's character, (a) God's engagement and (b) God's judgment, we explored the relationship between images of God and the broad concept of religious conservatism. Taken together, we find that engaged and judgmental images of God are significantly related to conservative religious beliefs, increased religious involvement, and attitudes supporting a closer connection between religion and the state. As such, images of God predict multiple aspects of the religious lives of Americans.

Leibniz hypothesis that that Spinoza's natural conception of God would erode traditional religious behavior and commitment receives support from our findings. We demonstrate that Americans who believe that God is less engaged or autonomous attend church less often, tend to interpret the Bible metaphorically, and believe that religious and secular concerns are mutually exclusive. While Leibniz was correct in his understanding of the relationship between images of God and religious conservatism, any fear that traditional religion in the United States is in danger remains unfounded. Simply put, few Americans believe in Spinoza's God even though the United States is one of the most modern societies in the world.

While beliefs about God's judgment and God's engagement are highly correlated, they affect the religious lives and attitudes of Americans in different ways. Images of a judgmental God are most closely related to feelings that one's religious faith is exclusively the correct path and lead individuals to more easily condemn those who hold different beliefs. In addition, individuals with more judgmental images of God tend to think that God is intimately involved in politics and that God favors the United States and the Republican Party. In sum, believers in a judgmental God tend to reject the idea that the religious and secular spheres are or can be distinct.

But, surprisingly, a judgmental God is unrelated to whether individuals go to church, have religious experiences, or share their faith with others. Instead, it is the belief that God is engaged 
in the world that is associated with higher expressions of religious involvement and commitment. Because judgmental images of God influence religious behavior less than engaged images of God, we might begin to look at religious motivations in new ways. Are conceptions of God a stick or a carrot in motivating human behavior? Based on our findings, we hypothesize that religious behavior is influenced through God's perceived closeness to the individual more so than fear of God's wrath. Therefore, religion may most successfully motivate individuals through what it can offer them in spiritual intimacy, rather than through demands backed by threats of punishment.

A wealth of sociological literature indicates that Christian evangelicalism has become a growing and influential force in contemporary societies (Evans 1997; Guinness 1993; Hunter 1991; Smith 1998; Wuthnow 1988, 1996). Evangelicalism is mainly defined, while difficult to accurately measure, as stressing interpersonal relationships with God. Using data from a series of detailed interviews, Christian Smith (1998) argues that the relational aspect of Christianity has led to the strength and growth of American evangelicalism. Based on these and our findings, religious vitality appears dependent on the idea of a God who is intimately engaged in believers' lives. And Americans remain firm in their belief in an engaged God.

While our current study is confined to the predominately Christian United States, the concept of images of God may be productively applied to Islamic cultures. Measuring religious pluralism within the Islamic tradition is highly problematic but an indicator of individual beliefs about the nature of Allah could reveal the extent to which Muslims hold diverse beliefs. We expect that Muslims would vary in their conceptions of God as much as do Christians. But the extent to which Muslims hold judgmental and engaged images of Allah may indicate their potential acceptance of, or resistance to, the differentiation of religious and secular spheres in the areas of politics, education, and the law. In other words, images of Allah provide the basis for how the Islamic world encounters and ultimately copes with modernity. We urge future international or cross-national surveys to consider the inclusion of robust image of God measures.

In the United States, where there exists a long history of separation of church and state and a continued fascination with modern technology, many Americans still hold onto very traditional images of God. To be sure, higher levels of education are correlated with less traditional images of God but the larger profile of the American public is distinctly traditional. This demonstrates that modernity does not necessarily undermine engaged and judgmental images of God. And these images are intimately connected to the vibrant religious conservatism of many Americans today. For this reason, Leibniz would surely be pleased and Spinoza would most likely be mystified.

\section{Notes}

1. Religious wars tend to focus on disagreements about who has the one true God (see Armstrong 2000; Stark 2001). Large scale conflicts concerning atheism really only emerged during the Soviet era (see Froese 2004) and most communist regimes today have abandoned a virulent advocacy of atheism.

2. Respondents to the Baylor Religion Survey (described below and in Bader et al. in this issue) were asked "Which one statement comes closest to your personal beliefs about God?" Of valid responses, 4.3 percent "don't believe in anything beyond the physical world"; 14.2 percent believe in a higher power or cosmic force; 1.6 percent sometimes believe in God; 10.5 percent believe in God with some doubt; 69.4 percent have no doubts the God exists. If we allow some doubt in belief in God, the percent reporting belief increases to 95.7 percent.

3. Famously, Albert Einstein indicated that he believed in "Spinoza's God" (Brian 1997).

4. A number of labels have been used to distinguish more conservative religious believers from more liberal ones. For example, James Hunter (1991) writes about "orthodox" versus "progressive" religious believers, Davis and Robinson (1999) speak of "traditionalists" versus "modernists," and Stark and Finke (2000) refer to religious groups in higher and lower tension with their secular surroundings. These are all attempts to express the idea of religious conservatism.

5. All too often, researchers categorize individuals based on how "literally" they interpret the Bible. But the meaning of this measure is unclear, mainly because the Bible contains such a vast array of statements concerning the natural and supernatural worlds. Certain passages must emerge as more salient to those individuals who interpret the Bible literally. Yet it is difficult to know what those salient aspects of the Bible are. 
6. The success of recent books advocating atheism such as The God Delusion by Richard Dawkins and Breaking the Spell by Daniel Dennett indicate that the topic of atheism is, at the very least, gaining interest among some Americans.

7. Respondents were asked to indicate (yes/no) if they experienced the following: witnessed or experienced a miraculous, physical healing; witnessed people speaking in tongues at a place of worship; spoke in tongues at a place of worship; had a vision of a religious figure while awake; felt called by God to do something; heard the voice of God; had a dream of religious significance; changed profoundly as the result of a religious experience; had a religious conversion experience.

8. The religious experiences variable has a limited range (0-9), with decreasing numbers of cases as experiences increase. Therefore, we also ran this model using Poisson regression and TOBIT. The directions and levels of significance remained the same for our religion variables in OLS, TOBIT, and Poisson models. For simplicity of presentation, we provide the results of the OLS regression in Table 3.

9. We would like to thank Rhys Williams and Chris Ellison for this suggestion.

10. Given the number of religion measures included in the models we ran multicollinearity diagnostics on all OLS regressions. In no cases were VIF scores above 4 and the average VIF score for any given model was always lower than 2.0. Full multicollinearity diagnostics available upon request.

\section{REFERENCES}

Akerlof, G. A. 1997. Social distance and social decisions. Econometrica 65:1005-27.

Armstrong, K. 2000. The battle for God. New York: Ballantine Books.

Benson, P. and B. Spilka. 1973. God image as a function of self-esteem and locus control. Journal for the Scientific Study of Religion 12:297-310.

Berheim, B. D. 1995. A theory of conformity. Journal of Political Economy 102:841-77.

Brian, D. 1997. Einstein: A life. New York: Wiley.

Davis, N. J. and R. V. Robinson. 1999. Their brothers' Keepers? Orthodox religionists, modernists, and economic justice in Europe. American Journal of Sociology 104(6):1631-65.

Dougherty, K., B. Johnson, and E. Polson. 2007. Recovering the lost: Remeasuring U.S. religious affiliation. Journal for the Scientific Study of Religion 46(4);483-99.

Ellison, C. 1991. An eye for an eye? A note on the southern subculture of violence thesis. Social Forces 69(4):122339.

Evans, J. H. 1997. Worldviews or social groups as the source of moral value attitudes: Implications for the culture wars thesis Sociological Forum 12(3):371-404.

Froese, P. 2004. Forced secularization in Soviet Russia: Why an atheistic monopoly failed. Journal for the Scientific Study of Religion 43:1, 35-50.

Froese, P., C. Bader, and B. Smith. Forthcoming. Political tolerance and God's wrath in the United States. Sociology of Religion.

Green, J. C., J. L. Guth, C. E. Smidt, and L. A. Kellstedt. 1996. Religion and the culture wars: Dispatches from the front. Lanham, MD: Rowman \& Littlefield.

Gorsuch, R. L. 1968. The conceptualization of God as seen in adjective ratings. Journal for the Scientific Study of Religion 7(1):56-64.

Gorsuch, R. L. and C. S. Smith. 1983. Attributions of responsibility to God: An interaction of religious beliefs and outcomes. Journal for the Scientific Study of Religion 22(4):340-52.

Greeley, A. M. 1988. Evidence that a maternal image of God correlates with liberal politics. Sociology and Social Research 72:150-54.

1989. Religious change in America. Cambridge, MA: Harvard University Press.

1991. Religion and attitudes towards AIDS policy. Sociology and Social Research 75:126-32.

1993. Religion and attitudes toward the environment. Journal for the Scientific Study of Religion 32:19-28.

1995. Religion as poetry. New Brunswick, NJ: Transaction Publishers.

Guinness, O. 1993. The American hour. New York: Free Press.

Hunter, J. D. 1991. Culture wars: The struggle to define America. New York: Basic Books.

Iannaccone, L. 1994. Why strict churches are strong. American Journal of Sociology 99:1180-1211.

Ladd, K., D. N. McIntosh, and B. Spilka. 1998. Children's God concepts: Influences of denomination, age and gender. International Journal for the Psychology of Religion 8(1):49-56.

Leibniz, G. W. 1961. Discourse on metaphysics. New York: Barnes \& Noble.

Nelsen, H. M., N. H. Cheek, Jr., and P. Au. 1985. Gender differences in images of God. Journal for the Scientific Study of Religion 24:396-402.

Norris, P. and R. Inglehart. 2004. Sacred and secular: Religion and politics worldwide. Cambridge: Cambridge University Press.

Roberts, C. W. 1989. Imagining God: Who is created in whose image? Review of Religious Research 30:375-86.

Schoenfeld, E. 1987. Images of God and man: An exploratory study. Review of Religious Research 28:224-35. 
Sen, A. 1993. Internal consistency of choice. Econometrica 61:495-521.

Sherkat, D. and C. Ellison. 1999. Recent developments and current controversies in the sociology of religion. Annual Review of Sociology 25:363-94.

Simmel, G. [1904] 1997. Religion and the contradictions in life. In Essays on religion. Translated by Phillip E. Hammond, p. 53. New Haven and London: Yale University Press.

Smith, C. 1998. American evangelicalism: embattled and thriving. Chicago: Chicago University Press.

. 1989. Tractatus theologico-politicus. Translated by Samuel Shirley. New York: E.J. Brill.

Stark, R. 2001. Gods, rituals, and the moral order. Journal for the Scientific Study of Religion 40(4):619-36.

Stark, R. and R. Finke. 2000. Acts of faith: Explaining the human side of religion. Berkeley, CA: University of California Press.

Stark, R. and W. Bainbridge. 1985. The future of religion: Secularization, revival and cult formation. Berkeley, CA: University of California Press.

Steensland, B., J. Z. Park, M. D. Regnerus, L. D. Robinson, W. B. Wilcox, and R. D. Woodberry. 2000. The measure of American religion: Toward improving the state of the art. Social Forces 79(1):291-318.

Stewart, M. 2006. The courtier and the heretic: Leibniz, Spinoza, and the fate of God in the modern world. New York: WW Norton \& Company.

Unnever, J., F. T. Cullen, and B. Applegate. 2005. Turning the other cheek: Reassessing the impact of religion on punitive ideology. Justice Quarterly 22(3):304-38.

Unnever, J. D., F. T. Cullen, and J. P. Bartkowski. 2006. Images of God and public support for capital punishment: Does a close relationship with a loving God matter? Criminology 44(4):835-66.

Williams, R. H. 1999. Visions of the good society and the religious roots of American political culture. Sociology of Religion 60(1):1-34.

Woodberry, R. D. and C. Smith. 1998. Fundamentalism et al.: Conservative Protestants in America. Annual Review of Sociology. Palo Alto, CA: Annual Reviews.

Wuthnow, R. 1988. The restructuring of American religion: Society and faith since World War II. Princeton, NJ: Princeton University Press.

1996. The restructuring of American religion: Further evidence. Sociological Inquiry 66:303-29. 
Copyright of Journal for the Scientific Study of Religion is the property of Blackwell Publishing Limited and its content may not be copied or emailed to multiple sites or posted to a listserv without the copyright holder's express written permission. However, users may print, download, or email articles for individual use. 